Texas A\&M University-San Antonio

Digital Commons @ Texas A\&M University- San Antonio

2016

\title{
Statistical Analysis of Paradigmatic Class Richness Supports Greater Paleoindian Projectile-Point Diversity in the Southeast
}

M. I. Eren
A. Chao
C. H. Chiu
R. K. Colwell
B. Buchanan

See next page for additional authors

Follow this and additional works at: https://digitalcommons.tamusa.edu/hist_faculty

Part of the Anthropology Commons

\section{Repository Citation}

Eren, M. I.; Chao, A.; Chiu, C. H.; Colwell, R. K.; Buchanan, B.; Boulanger, M. T.; Darwent, J.; and O'Brien, Michael J., "Statistical Analysis of Paradigmatic Class Richness Supports Greater Paleoindian ProjectilePoint Diversity in the Southeast" (2016). History Faculty Publications. 22.

https://digitalcommons.tamusa.edu/hist_faculty/22

This Article is brought to you for free and open access by the College of Arts and Sciences at Digital Commons @ Texas A\&M University- San Antonio. It has been accepted for inclusion in History Faculty Publications by an authorized administrator of Digital Commons @ Texas A\&M University- San Antonio. For more information, please contact deirdre.mcdonald@tamusa.edu. 


\section{Authors}

M. I. Eren, A. Chao, C. H. Chiu, R. K. Colwell, B. Buchanan, M. T. Boulanger, J. Darwent, and Michael J. O'Brien 


\title{
STATISTICAL ANALYSIS OF PARADIGMATIC CLASS RICHNESS SUPPORTS GREATER PALEOINDIAN PROJECTILE-POINT DIVERSITY IN THE SOUTHEAST
}

\author{
Metin I. Eren, Anne Chao, Chun-Huo Chiu, Robert K. Colwell, Briggs Buchanan, \\ Matthew T. Boulanger, John Darwent, and Michael J. O'Brien
}

\begin{abstract}
Ronald Mason's hypothesis from the 1960s that the southeastern United States possesses greater Paleoindian projectile-point diversity than other regions is regularly cited, and often assumed to be true, but in fact has never been quantitatively tested. Even if valid, however, the evolutionary meaning of this diversity is contested. Point diversity is often linked to Clovis "origins," but point diversity could also arise from group fissioning and drift, admixture, adaptation, or multiple founding events, among other possibilities. Before archaeologists can even begin to discuss these scenarios, it is paramount to ensure that what we think we know is representative of reality. To this end, we tested Mason's hypothesis for the first time, using a sample of 1,056 Paleoindian points from eastern North America and employing paradigmatic classification and rigorous statistical tools used in the quantification of ecological biodiversity. Our first set of analyses, which compared the Southeast to the Northeast, showed that the Southeast did indeed possess significantly greater point-class richness. Although this result was consistent with Mason's hypothesis, our second set of analyses, which compared the Upper Southeast to the Lower Southeast and the Northeast showed that in terms of point-class richness the Upper Southeast > Lower Southeast > Northeast. Given current chronometric evidence, we suggest that this latter result is consistent with the suggestion that the area of the Ohio, Cumberland, and Tennessee River valleys, as well as the mid-Atlantic coastal plain, were possible initial and secondary "staging areas" for colonizing Paleoindian foragers moving from western to eastern North America.
\end{abstract}

La hipótesis de Ronald Mason sobre el hecho de que la diversidad de puntas de proyectil es mayor en el SE de los Estados Unidos que en otras regiones se cita habitualmente y se asume con frecuencia como cierta. Sin embargo, nunca ha sido comprobada cuantitativamente. Incluso, aun siendo válida, el sentido evolutivo de tal diversidad es cuestionable. La variabilidad de puntas se relaciona frecuentemente con el "origen" de los Clovis, pero podría obedecer también a la división y deriva del grupo, a la mezcla, a procesos adaptativos, o a múltiples eventos radicados en el sudeste, entre diversas posibilidades. Antes incluso de que tales escenarios puedan comenzar a discutirse desde la Arqueología, es de suma importancia asegurar que lo que creemos saber es representativo de la realidad. Con esta finalidad, hemos comprobado la hipótesis de Mason por primera vez, usando una muestra de 1056 puntas paleoindias del Este de América del Norte, con una clasificación paradigmática y herramientas estadísticas rigurosas para la cuantificación de la diversidad biológica. Nuestro primer conjunto de análisis, que comparaba el SE con el NE, mostraba que la diversidad de las puntas de proyectil en el ámbito suroriental es, incluso, significativamente mayor. A pesar de que este resultado es coherente con la hipótesis de Mason, nuestro segundo conjunto de análisis que comparaba el Sudeste superior frente al inferior y frente al Noreste, mostraba que tal diversidad decrece desde el Sudeste superior hasta el último. Dado las actuales evidencias cronométricas, sugerimos de manera provisional que este resultado es coherente con el sugerencia que la zona de Ohio, Cumberland y el valle del Río Tennessee, así como la llanura costera del Atlántico central fueron posibles "escalas" en la colonización de los recolectores paleoindios, que se desplazaban desde el oeste al este de Norteamérica.

Metin I. Eren - Department of Anthropology, Kent State University, Kent, OH, 44242; Department of Archaeology, Cleveland Museum of Natural History, Cleveland, OH 44106-1767, U.S.A. (m.i.eren10@gmail.com) (corresponding author) Anne Chao and Chun-Huo Chiu $\square$ Institute of Statistics, National Tsing Hua University, Hsin-Chu, 30043, Taiwan (chao@stat.nthu.edu.tw; otterfinder@yahoo.com.tw)

Robert K. Colwell a University of Colorado Museum of Natural History, Boulder, CO 80309; Departmento de Ecologia, Universidade Federal de Goiás, CP 131, 74.001-970, Goiânia, GO, Brasil; Department of Ecology and Evolutionary Biology, University of Connecticut, Storrs, CT (colwell@uconn.edu)

Briggs Buchanan - Department of Anthropology, University of Tulsa, Tulsa, OK 74104, (briggs-buchanan@utulsa.edu) Matthew T. Boulanger $\square$ Department of Anthropology, Southern Methodist University, Dallas, TX, 75275-0235

(boulangerm@missouri.edu)

John Darwent Department of Anthropology, University of California-Davis, Davis, CA 95616-8522 (jadarwent@ucdavis.edu) Michael J. O’Brien - Department of Anthropology, University of Missouri, Columbia, MO, 65211 (ObrienM@missouri.edu)

American Antiquity 81(1), 2016, pp. 174-192

Copyright (C) 2016 by the Society for American Archaeology

DOI: $10.7183 / 0002-7316.81 .1 .174$ 
$\mathrm{F}$ or over 50 years, archaeologists have asserted that Paleoindian projectile-point diversity is greater in the southeastern United States, as a whole or in part, than in other geographic regions. To our knowledge, Mason (1962:235) was the first to make this claim formally, ${ }^{1}$ stating that "this area [the Southeast] . . . has produced the greatest diversification in fluted point styles." Several studies have cited Mason's assertion, usually with the caveat that it needs testing (Anderson and Faught 1998; Beck and Jones 2010; Brennan 1982; Bryan 1991; Greenman 1963; Meltzer 2004; Miller and Gingerich 2013a, 2013b; O'Brien et al. 2001 , 2014; Stanford 1991; Stanford and Bradley 2012; Williams and Stoltman 1965). Others have proposed that specific areas within the Southeast have relatively greater point diversity. For example, Broster et al. recently suggested, "the Paleoindian record of Tennessee is more diverse, in terms of point types, than that in virtually all other areas of North America." They also note, however, that "additional research is needed to definitively prove this hypothesis" (Broster et al. 2013:304).

By "diversity," Mason (1962), Broster et al. (2013), and others (e.g., Anderson and Faught $1998,2000)$ are referring specifically to the concept of "richness," defined as the number of species or classes in an assemblage, the most intuitive concept for characterizing assemblage (community) diversity (Chao 2005; Colwell et al. 2012; Eren et al. 2012; Gotelli and Colwell 2011; Magurran 2004). The caution often associated with assertions of greater southeastern point diversity is warranted for three reasons. First, there has never been a quantitative or statistical analysis of point diversity, either within the Southeast or between the Southeast and other regions. Instead, assessments of diversity have been based on subjective impressions and intuition. Second, the analytical units, i.e., point "types," used in proposals of southeastern diversity are themselves often subjective, fuzzy, inconsistent amalgams of different character states. Anderson and Faught (1998:173) note, "it is no exaggeration to state that this region [the Southeast] has more distinct named varieties of fluted and related forms than any other part of the United States." But do these named varieties truly reflect greater point diversity or simply a local southeastern nomenclature tradition focused on "splitting" rather than "lumping" (O'Brien and Lyman 2002; O’Brien et al. 2001, 2002)? Third, and perhaps most problematic, is the well-known fact that richness is sample-size dependent; as sample size increases, so too can observed richness (Haavie et al. 2000; Leberg 2002; Lyman 2008). Several studies have now demonstrated that point sample sizes are correlated with modern population distribution and/or density, level of collector activity, intensity of prior archaeological research, years since statehood, modern land-use patterns, and acreage of urban development (Buchanan 2003; Lepper 1983, 1985; Loebel 2012; Meltzer 1986; Prasciunas 2011; Seeman and Prufer 1982, 1984; Shott 2002; Wiant 1993). In fact, particular parts of the Southeast have extraordinarily high point counts (Anderson 1996; Anderson and Faught 1998, 2000; Anderson et al. 2010), and thus the currently perceived greater point richness in the Southeast may simply be a result of greater sample size.

What greater southeastern point richness - if valid-might mean for the broader question of the peopling of the Americas is also contested. Mason (1962; see also Beck and Jones 2010) suggested that the greater point richness in the Southeast possibly indicated that it was the "homeland" of the Clovis complex, which comprises tools representing the earliest widespread and currently recognizable remains of hunter-gatherers in late Pleistocene North America (Anderson 1990; Anderson and Gillam 2000; Barton et al. 2004; Bradley et al. 2010; Haynes 2002; Holliday and Miller 2014; Meltzer 2009; Miller et al. 2014; Sanchez et al. 2014; Sholts et al. 2012; Smallwood 2012; Smallwood and Jennings 2015; Steele et al. 1998). Mason's (1962) diversity proposal might be seen as broadly analogous to the iterative founder-effect model in population genetics and cultural-transmission theory, which predicts a sequential reduction of within-population variance as a result of repeated instances of reduced effective population sizes (serial bottlenecking) along a dispersal route (Lycett 2008; Lycett and von Cramon-Taubadel 2008; Prugnolle et al. 2005). However, it is worth noting that correctly implemented, the founder effect is a statement about within-population variance (Lycett 2008; Lycett and von Cramon-Taubadel 2008), not specifically about between-group diversity. 
Indeed, greater point richness in the Southeast, or in parts of the Southeast, may have arisen as a result of a combination of demographic, cultural, environmental, and/or colonization-behavior factors. For example, southeastern environments may have supported larger Paleoindian populations relative to other regions, resulting in increased group fissioning (Anderson 1990). Over space and time, this increased fissioning might conceivably have led to increased occurrence of technological drift (Eren et al. 2015; O'Brien et al. 2014; Smith et al. 2015) and hence greater point richness. Similarly, if certain river valleys of the Southeast were used as colonization corridors (Anderson 1990, 1996), they may have possessed greater populations relative to other areas, resulting in a greater rate of fissioning, technological drift, and point richness. Other explanations for this diversity could include admixture, adaptation, or multiple founding events (Lycett and von Cramon-Taubadel 2008). Given the paucity of radiocarbon dates robustly associated with Paleoindian points in the Southeast (Beck and Jones 2010; Meltzer 2004; Miller and Gingerich 2013a), as well as the lack of unequivocal pre-Clovis occupations, distinguishing between hypotheses such as the "origins" and "fissioning" scenarios described above is not currently possible. However, given that both hypotheses involve greater southeastern point richness, it is critical to establish whether the Southeast does in fact possess greater point richness than other regions. Here we put this long-held, widespread assertion to the test by statistically assessing southeastern Paleoindian point richness against that for the Northeast. We also conduct a three-way comparison among the "Lower" Southeast, the "Upper" Southeast, and the Northeast to determine whether one specific area of the Southeast is significantly richer than the other.

\section{Materials and Methods}

To these ends, we use a sample of points from eastern North America, explicitly defined point classes, and statistical tools designed to standardize samples on the basis of size and completeness and facilitate the comparison of communities, even if sample sizes are different (Chao et al. 2014; Colwell et al. 2012).

\section{Samples}

Numerous studies, both published and unpublished, have compiled metric data on large samples of projectile points from eastern North America (e.g., Anderson et al. 1990; Meltzer 1984; Tankersley 1989; Thulman 2006). In some cases, such data are available through the Paleoindian Database of the Americas, or PIDBA (Anderson et al. 2010). Each of these datasets, however, was created to address a specific purpose or research question being posed by a particular researcher. Metric and nonmetric variables (characters) recorded by each researcher are inconsistent across datasets, and, perhaps more significantly, there is inherent variability in how different researchers record attributes of artifacts (Beck and Jones 1989; Lyman and VanPool 2009). Without the ability to remeasure many of the same artifacts so that interobserver variation can be evaluated, there is no way to validate the quality of the data and to assess variation in data collection. This discussion is not meant to diminish the merit and utility of PIDBA or of previous studies on Paleoindian point forms. Rather, we only wish to explain why we chose not to aggregate the varied constituent databases into a single dataset; doing so would introduce interobserver measurement error that cannot be quantified (or even evaluated), and it would require removal of characters to ensure parity among the datasets.

For this reason, our sample consists of 1,056 points ${ }^{2}$ from eastern North America and of types traditionally assigned to the Paleoindian period $(12,800-11,000 \mathrm{cal}$ B.P.). The range of specimens starts with Clovis and ends with Dalton (O'Brien et al. 2014). The regional distribution of specimens is shown in Table 1. As described by O'Brien et al. (2001, 2002, 2014), measurements and characters were recorded from actual specimens as well as from high-quality drawings and photographs. Although the database is continually expanding, our sample is already statistically robust. References for all specimens were likewise recorded and are available in the supplemental online materials. Further details on the Paleoindian points used in our analyses can be found in O’Brien et al. (2014).

\section{Paradigmatic Classes}

The classification of projectile points in eastern 
Table 1. The Distribution by State of Paleoindian Projectile-Points Included in This Study $(\mathrm{n}=1,056)$.

\begin{tabular}{lccc}
\hline State/Province & $\mathrm{n}$ & Analysis 1 & Analysis 2 \\
\hline Alabama & 170 & $\mathrm{SE}$ & Lower SE \\
Arkansas & 32 & $\mathrm{SE}$ & Upper SE \\
Connecticut & 2 & $\mathrm{NE}$ & NE \\
Florida & 31 & $\mathrm{SE}$ & Lower SE \\
Georgia & 7 & $\mathrm{SE}$ & Lower SE \\
Indiana & 3 & $\mathrm{NE}$ & NE \\
Kentucky & 92 & $\mathrm{SE}$ & Upper SE \\
Louisiana & 1 & $\mathrm{SE}$ & Lower SE \\
Maine & 42 & $\mathrm{NE}$ & $\mathrm{NE}$ \\
Massachusetts & 21 & $\mathrm{NE}$ & $\mathrm{NE}$ \\
Mississippi & 51 & $\mathrm{SE}$ & Lower SE \\
Missouri & 92 & $\mathrm{SE}$ & Upper SE \\
New Hampshire & 8 & $\mathrm{NE}$ & $\mathrm{NE}$ \\
New Jersey & 9 & $\mathrm{NE}$ & $\mathrm{NE}$ \\
New York & 83 & $\mathrm{NE}$ & $\mathrm{NE}$ \\
North Carolina & 13 & $\mathrm{SE}$ & Upper SE \\
Nova Scotia & 5 & $\mathrm{NE}$ & NE \\
Ohio & 1 & $\mathrm{NE}$ & NE \\
Ontario & 3 & $\mathrm{NE}$ & NE \\
Pennsylvania & 93 & $\mathrm{NE}$ & NE \\
South Carolina & 5 & $\mathrm{SE}$ & Lower SE \\
Tennessee & 205 & $\mathrm{SE}$ & Upper SE \\
Vermont & 20 & $\mathrm{NE}$ & NE \\
Virginia & 65 & $\mathrm{SE}$ & Upper SE \\
West Virginia & 2 & $\mathrm{NE}$ & NE \\
TOTAL & 1,056 & & \\
\hline
\end{tabular}

North America has typically relied on the use of taxonomic units, i.e., types. Anderson et al. (2010:75) note, with respect to the southeastern Paleoindian archaeological record in particular, "It is critical that when people type points, they should provide their criteria . . . so other researchers can evaluate their classifications." External evaluation of classifications is necessary because the projectile-point types commonly used in the east are extensionally defined (Dunnell 1971) and lack clearly stated conditions of membership, thus leading to disagreements concerning how individual specimens should be classified. Definitions of types can vary such that definitive criteria are different from one researcher to another (see O'Brien et al. 2014), and, as Whittaker et al. (1998) demonstrate, what a type signifies to an individual is biased by personal experience, educational pedigree, and knowledge. Anderson (2013:372) states that analyses of point variability should "proceed independently from existing typological biases and preconceptions, at least as much as possible" (see also Carr and Bradbury
2000). We agree with this statement in large part because there is no a priori reason to assume that extant projectile-point types are universally useful for all research questions.

In contrast to taxonomic classification, paradigmatic classification is specifically intended to document and monitor morphological variation in a manner that is explicit, and unbiased by the experiences of the analyst (Dunnell 1971; O'Brien and Lyman 2000). Paradigmatic classification proceeds as follows. The analyst enumerates the characters and defines all mutually exclusive states of each character. Specimens are then examined and the state of each character is registered. Specimen classes arise from the unique combinations of character states, scoring each specimen with one character state for each character, to classify it. Importantly, the analyst need not observe specimens exhibiting each potential combination of character states, or, as O'Brien and Lyman (2000:199) put it, "One can conceive of a 12inch-long red pencil, but one need not have an actual specimen displaying this combination of length and color attributes to realize that such a thing may exist." Empty or unrepresented space within a paradigmatic classification provides useful information because it reveals which combinations of morphological attributes were never combined with each other, perhaps giving clues as to functional constraints or to the presence of cultural traditions.

Units (classes) created by paradigmatic classification have several advantages over taxonomically and extensionally defined types (Dunnell 1971), one of which is that paradigmatic classes are explicit and unambiguous in terms of structure and membership criteria. From the perspective of measuring morphological diversity, a paradigmatic classification removes all confusion regarding how a specimen should be classified, and the classification process is absent of biases for "splitting" or "lumping" units. We acknowledge that intensionally defined (Dunnell 1971) paradigmatic classes are different from the traditional extensionally defined point "types" that archaeologists frequently use when discussing Paleoindian point forms. ${ }^{3}$ Yet, paradigmatic classification has seen usage in archaeology for a wide range of materials (e.g., Beck and Jones 1989; Eren 2012; Eren et al. 2012; Meltzer 1981; Nolan and Cook 2011; 
Table 2. Characters and Character States Used for the Projectile-Point Paradigmatic Classification.

\begin{tabular}{|c|c|c|c|c|c|c|c|}
\hline Character & Character States & & & & & & \\
\hline $\begin{array}{l}\text { Height of } \\
\text { maximum } \\
\text { blade width }\end{array}$ & $\begin{array}{c}\text { Proximal } \\
\text { quarter }\end{array}$ & $\begin{array}{l}\text { Secondmost } \\
\text { proximal } \\
\text { quarter }\end{array}$ & $\begin{array}{c}\text { Thirdmost } \\
\text { proximal } \\
\text { quarter }\end{array}$ & $\begin{array}{l}\text { Distal } \\
\text { quarter }\end{array}$ & & & \\
\hline Overall base shape & Arc/Round & Normal curve & Triangular & Folsomoid & Flat & Convex & \\
\hline Basal-indentation ratio & No indentation & $.90-.99$ & $.80-.89$ & $.70-.79$ & $.60-.69$ & $.50-.59$ & \\
\hline Constriction ratio & 1.00 & $.90-.99$ & $.80-.89$ & $.70-.79$ & $.60-.69$ & $.50-.59$ & $.40-.49$ \\
\hline Outer tang angle (degrees) & $93-115$ & $88-92$ & $81-87$ & $66-80$ & $51-65$ & 50 or greater & \\
\hline Tang-tip shape & Pointed & Round & Blunt & & & & \\
\hline Fluting & Absent & Present & & & & & \\
\hline Length:Width ratio & $1.00-1.99$ & $2.00-2.99$ & $3.00-3.99$ & $4.00-4.99$ & $5.00-5.99$ & 6.00 or greater & \\
\hline
\end{tabular}

O'Brien and Lyman 2002, 2009; O'Brien et al. 2001). And it is precisely the differences between taxonomically defined types and paradigmatic classes that make paradigmatic classification an ideal tool to fulfill Anderson et al.'s (2010; see also Anderson 2013) specifications for creating analytical units, i.e., point taxa.

We followed the protocol of O'Brien et al. $(2001,2002,2014)$ in classifying specimens. The protocol uses eight characters (each of which has a number of character states): (1) height of maximum blade width; (2) overall base shape; (3) basalindentation ratio; (4) constriction ratio; (5) outer tang angle; (6) tang-tip shape; (7) fluting; and (8) length:width ratio, each of which has a number of character states (Table 2). This particular set of characters and character states creates 217,728 classes $(4 \times 6 \times 6 \times 7 \times 6 \times 3 \times 2 \times 6=217,728$ [character 1's four character states multiplied by character 2's six character states multiplied by character 3's six character states, and so on]). We note, however, that of these 217,728 classes, only a small portion ( $\sim .33$ percent) of that available design space-the $n$-dimensional classification that is defined by the intersection of all possible character states of mutually exclusive characters (O’Brien et al. 2015) - actually contained classes with specimens $(n=725)$. We also note that future classifications might profitably benefit from using exclusively size-adjusted shape data.

\section{Analyses}

We conducted two sets of analyses. The first compared point richness between the Southeast and the Northeast (Figure 1). Our definition of the Southeast, following Anderson (1990), compromises: Alabama, Arkansas, Florida, Georgia, Kentucky,
Louisiana, Mississippi, North Carolina, South Carolina, Tennessee, and Virginia. ${ }^{4}$ The Northeast comprises Maine, Vermont, New Hampshire, Massachusetts, Connecticut, New York, New Jersey, Pennsylvania, Ohio, West Virginia, Indiana, Missouri, and the two Canadian provinces of Nova Scotia and Ontario.

The second analysis was based on research by Anderson (1990, 1996), Smallwood (2012), and Broster et al. (2013). Anderson $(1990,1996)$ and Smallwood (2012) suggest that the area of the Ohio, Cumberland, and Tennessee River valleys, as well as the mid-Atlantic coastal plain, were possible initial and secondary "staging areas" for colonizing Paleoindian foragers because they are rich in biotic and stone resources. Anderson (1996) further suggests that rivers such as the Missouri, Arkansas, and Mississippi may have been favorable transportation arteries to the aforementioned river valleys. Finally, recall Broster et al.'s (2013:304) proposal that "the Paleoindian record of Tennessee is more diverse, in terms of point types, than that in virtually all other areas of North America." Based on these statements, we wondered whether the Upper Southeast might be significantly richer than the Lower Southeast or the Northeast. We thus performed a three-way richness comparison among these three regions (Figure 2).

\section{Statistical Methods I}

To quantify the diversity of projectile points, we consider three measures: class richness, common class richness, and dominant class richness. Each has been used to extract useful information from complex data in various disciplines, including biology, ecology, economics, physics, and information sciences, but they have seen limited use in 


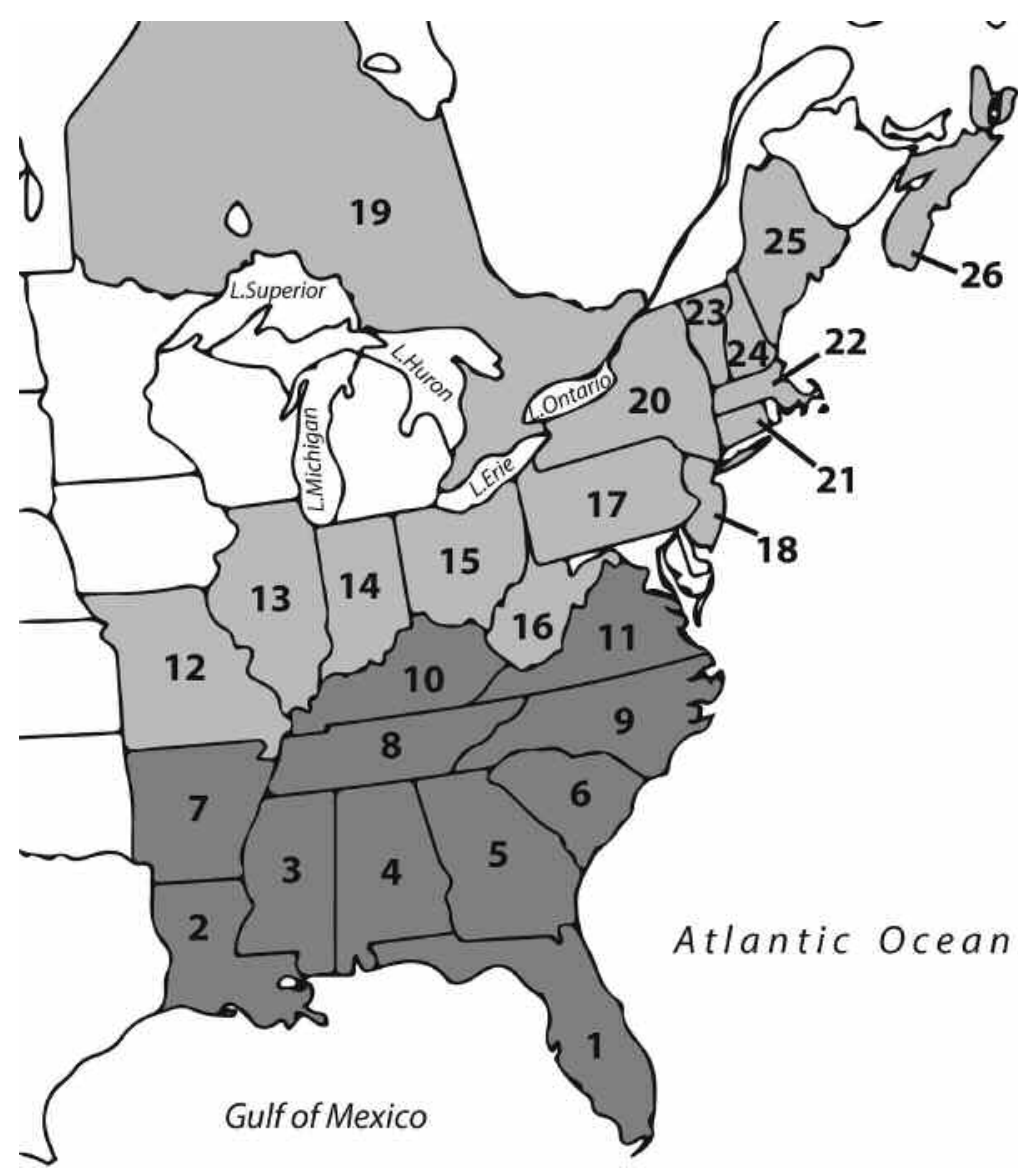

Figure 1. The first set of statistical analyses compared the diversity of Paleoindian projectile points from the Southeast (darker gray) to the diversity of points from the Northeast (lighter gray). ${ }^{5}$

archaeology. These three measures, as described below, are instances of a single mathematical function, differing only by an integer exponent (Gotelli and Chao 2013).

Class Richness (or diversity of order $q=0$ ). As noted earlier, class richness is the most intuitive diversity measure - the number of classes or categories represented by the objects in an assemblage, including not only the number of classes represented in samples but also the number of classes present in the assemblage that are not detected in the samples. Class richness satisfies all essential mathematical properties that implicitly underlie most biological thinking about diversity, but it is statistically difficult to accurately estimate class richness in most applications, especially for hyperdiverse assemblages (Colwell et al. 2012; Gotelli and Chao 2013). The difficulty arises from the unequal abundances of different classes that characterize archaeological assemblages, just as it does the species in biological assemblages. As sampling progresses, common classes are soon revealed, whereas rarer classes appear more slowly. If a large number of rare classes in an assemblage remains undetected in samples-as is the case with many archaeological data - then undersampling bias can be substantial. For severely undersampled data, the best we can do is to infer a minimum value of class richness. Here, we adopt the Chaol lower bound (Chao 1984) as the estimated asymptote of class richness. Chao1 is a widely used, nonparametric richness estimator that relies on the number of singletons (the number of classes represented by only one object in the observed sample) and doubletons (the number of classes represented by exactly two objects in the sample) to estimate the number of undetected classes in an assemblage, which is then added to 


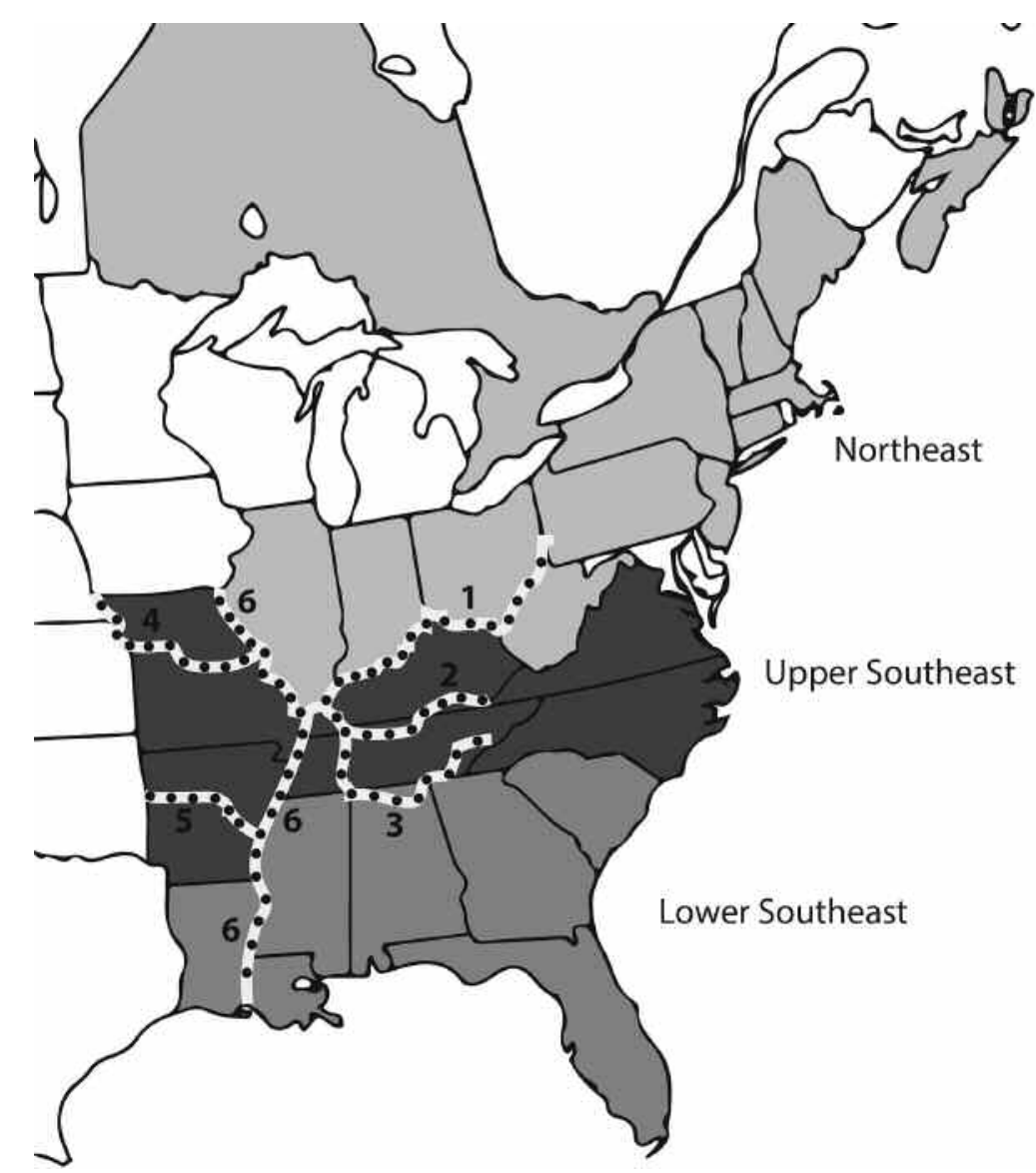

Figure 2. The second set of statistical analyses compared the diversity of Paleoindian projectile points from three areas: the Lower Southeast, the Upper Southeast, and the Northeast. ${ }^{6}$

the observed number of classes to estimate true richness. If there are no singletons, then the observed richness is approximately correct, whereas the presence of many singletons indicates that additional classes remain undetected.

Common Class Richness (Shannon diversity, diversity of order $q=1$ ). Shannon entropy (Shannon 1948) has been used to quantify the class uncertainty of an individual randomly selected from an assemblage. It was first used in information science and later adopted by ecologists to quantify the diversity of assemblages. However, Shannon entropy is in units of information and does not satisfy even the most fundamental property, the replication principle, which states that if $K$ equally large, equally diverse assemblages with no shared classes are pooled, then the diversity of the pooled assemblages equals $K$ times the diversity of an individual assemblage. To overcome this defi- ciency, MacArthur (1965) and Hill (1973) transformed the Shannon measure to its exponential so that the resulting measure is in units of "class equivalents" (the effective number of classes), thus behaving like class richness and satisfying all required essential properties. This measure is referred to as Shannon diversity (Chao et al.2014) or Hill number of order $q=1$ (Hill 1973; Jost 2007). Unlike class richness, however, which enumerates all classes as equivalent, whether common or rare, Shannon diversity counts classes in proportion to their relative abundance. Common classes contribute relatively more to the total diversity than do rare classes. Thus, Shannon diversity is interpreted as the (equivalent) number of common classes. Because the undetected classes in a sample are usually those with low relative abundances, their effect on Shannon diversity is less than their effect on observed class richness, 
but Shannon diversity is nonetheless subject to substantial undersampling bias. However, as with richness, statistical estimation methods can be applied to reduce this bias for Shannon diversity. The estimation of Shannon diversity in an entire assemblage, i.e., the asymptote of Shannon diversity, from incomplete samples is surprisingly nontrivial (see Chao et al. 2013 for a review). Here, we use the low-bias estimator proposed by Chao et al. (2013) as the estimated asymptote of Shannon diversity. This estimator, unlike Chao1, depends on all the observed frequencies in the observed sample.

Dominant Class Richness (Simpson diversity, diversity of order $q=2$ ). The Simpson diversity measure originated from the Gini-Simpson index (Gini 1912; Simpson 1943), which gives the probability that two randomly selected individuals belong to different classes. The one-complement of this index is known as the Simpson concentration index. Because it is a probability, the Gini-Simpson index does not satisfy the replication principle and thus does not behave as ecologists (or archaeologists) expect. MacArthur (1965) and Hill (1973) transformed the Simpson concentration to its inverse so that the resulting measure is in units of "class equivalents," or effective number of classes (like Shannon diversity), which satisfies all essential properties. This measure disproportionately discounts rare classes and emphasizes the common ones, so it is interpreted as the (equivalent) number of dominant or very common classes; it is also referred to as Simpson diversity (Chao et al. 2014) and Hill number of order $q=2$ (Hill 1973; Jost 2007). Given that dominant classes always appear in samples and undetected classes are discounted, Simpson diversity can often be quite accurately measured. In our analyses, we use the nearly unbiased estimator (Gotelli and Chao 2013) as the estimated asymptote of Simpson diversity. Because rare classes contribute little to this estimator, it is computed from the frequencies of abundant classes (frequencies $=2$ ) in the observed sample.

\section{Statistical Methods II}

For a given diversity measure, the goal is to make fair comparison and assessment of diversities across multiple assemblages. It is well known that class richness based on sampling data is highly dependent on sample size (Colwell and Coddington 1994). Chao et al. (2014) showed that Shannon diversity is moderately dependent and that Simpson diversity is weakly dependent on sample size and inventory completeness. The estimators described in the previous section reduce the effect of undersampling bias on richness, Shannon diversity, and Simpson diversity. However, additional control over this bias can be achieved by comparing samples at equivalent sample size or equivalent levels of completeness by means of sample-size-based rarefaction and extrapolation (Colwell et al.2012) and coverage-based rarefaction and extrapolation (Chao et al. 2014).

Sample-Size-Based Rarefaction and Extrapolation up to a Maximum Size. For each diversity measure, we compare all assemblages at equivalent sample sizes, which can be smaller than a particular observed sample (traditional rarefaction) or larger than an observed sample (extrapolation). We do this for a continuum of sample sizes by plotting diversity, for each assemblage, as a function of sample size up to a maximum size. For class richness, the size can be extrapolated, at most, to no more than double or triple the minimum observed sample size (Colwell et al. 2012). For Shannon diversity and Simpson diversity, if data are not sparse, the extrapolation can be reliably extended to infinity to attain the estimated asymptote.

Coverage-Based Rarefaction and Extrapolation up to a Maximum Coverage. Chao and Jost (2012) proposed comparing assemblages by plotting their diversities as a function of sample completeness, which is measured by sample coverage, an objective measure of sample completeness originally developed by the founder of modern computer science, Alan Turing, and his colleague I. J. Good (Good 1953, 2000). The sample coverage of a given sample is defined as the fraction of the individuals in an assemblage (including all undetected individuals) that belong to the classes observed in the sample. Contrary to intuition, sample coverage for the observed sample, rarified samples, and extrapolated samples can be accurately estimated by the observed data themselves. All samples are standardized by their sample coverage, which can be either smaller than the coverage of the observed sample size (rarefaction) or larger (extrapolation). The seamless rarefaction and ex- 
Table 3. Data Summary for the Southeast and the Northeast, with Statistical Inference for Estimated Asymptotes of Diversities (Unmerged Traits).

A. Data Summary with Anderson's (1990) Definition of the Southeast and the Northeast.

\begin{tabular}{lccccccccc}
\hline & $\begin{array}{c}\text { Sample } \\
\text { size } \mathrm{n}\end{array}$ & $\begin{array}{c}\text { Observed } \\
\text { richness }\end{array}$ & $\begin{array}{c}\text { Sample } \\
\text { coverage } \\
\text { (completeness) }\end{array}$ & $f_{1}$ & $f_{2}$ & $f_{3}$ & $f_{4}$ & $f_{5}$ & $f_{6}$ \\
\hline Southeast & 672 & 490 & $44.5 \%$ & 373 & 81 & 20 & 8 & 3 & 5 \\
Northeast & 384 & 293 & $39.4 \%$ & 233 & 42 & 9 & 6 & 2 & 1 \\
\hline
\end{tabular}

Note: $f_{k}$ denotes the number of classes represented by exactly $k$ individuals in the sample.

B. Observed Diversities and the Estimated Asymptotes of Diversities in the Southeast.

\begin{tabular}{lccccc}
\hline & & & & $\begin{array}{c}95 \% \text { lower } \\
\text { confidence } \\
\text { interval }\end{array}$ & $\begin{array}{c}95 \% \text { upper } \\
\text { confidence } \\
\text { interval }\end{array}$ \\
\hline Class richness & 490 & 1347.5 & 133.5 & 1123.2 & 1651.4 \\
Shannon diversity (common class richness) & 429.7 & 1131.3 & 67.3 & $999.3^{*}$ & $1263.2^{*}$ \\
Simpson diversity (dominant class richness) & 358.4 & 766.9 & 57.3 & $654.5^{*}$ & $879.2^{*}$ \\
\hline
\end{tabular}

* Interval does not overlap with the interval for the Northeast.

C. Observed Diversities and the Estimated Asymptotes of Diversities in the Northeast (C).

\begin{tabular}{|c|c|c|c|c|c|}
\hline & $\begin{array}{c}\text { Observed } \\
\text { richness }\end{array}$ & $\begin{array}{l}\text { Estimated } \\
\text { asymptote }\end{array}$ & $\begin{array}{c}\text { Estimated } \\
\text { s.e. }\end{array}$ & $\begin{array}{c}95 \% \text { lower } \\
\text { confidence } \\
\text { interval }\end{array}$ & $\begin{array}{c}95 \% \text { upper } \\
\text { confidence } \\
\text { interval }\end{array}$ \\
\hline Class richness & 293 & 937.6 & 132.9 & 725.1 & 1254.6 \\
\hline Shannon diversity (common class richness) & 261.2 & 788.6 & 62.9 & $665.3 *$ & $911.9 *$ \\
\hline Simpson diversity (dominant class richness) & 222.1 & 525.3 & 49.0 & $429.2 *$ & $621.3 *$ \\
\hline
\end{tabular}

* Interval does not overlap with the interval for the Southeast.

trapolation curve plots the diversity estimates as a function of sample coverage up to a maximum coverage. For class richness, the maximum coverage for comparing assemblages is specified to be the coverage corresponding of the maximum sample size used in the sample-size-based rarefaction and extrapolation curve, for each sample. For Shannon diversity and Simpson diversity, if data are not sparse, the extrapolation can often be extended to the coverage of unity to attain the estimated asymptote.

Discussion. The sample-size- and coveragebased integration of rarefaction and extrapolation represents a unified framework for estimating diversities and for comparing multiple assemblages based on these estimates. In both types of rarefaction and extrapolation, extrapolation is guided by an estimate of the asymptote of diversity, which is described under each diversity measure in the previous section. Chao et al. (2014) introduced a bootstrap method to construct 95 percent confidence intervals (CIs) associated with each estimated diversity measure. Generally, for any fixed sample size or any degree of completeness in the comparison, if the 95 percent CIs do not overlap, then significant differences at a level of 5 percent among the expected diversities (whether interpolated or extrapolated) are guaranteed. However, overlapped intervals do not guarantee nonsignificance (Colwell et al. 2012) and thus imply that data are inconclusive. All the rarefaction and extrapolation estimators and their CIs are available in the online freeware application iNEXT (http://chao.stat.nthu.edu.tw/blog/software-download/).

\section{Results}

The data summary for the Southeast and the Northeast, with statistical inference for estimated asymptotes of diversities, is presented in Table 3. The corresponding data summary and related inference for the Lower Southeast, the Upper Southeast, and the Northeast are shown in Table 4. The rarefaction and extrapolation curves for the two sets of data are shown in Figures 3 and 4, respectively. 
Table 4. Data Summary for the Lower Southeast, the Upper Southeast, and the Northeast, with Statistical Inference for Estimated Asymptotes of Diversities (Unmerged Traits).

A. Data Summary for the Lower Southeast, the Upper Southeast, and the Northeast.

\begin{tabular}{|c|c|c|c|c|c|c|c|c|c|}
\hline Area & $\begin{array}{c}\text { Sample } \\
\text { size } \mathrm{n}\end{array}$ & $\begin{array}{c}\text { Observed } \\
\text { richness }\end{array}$ & $\begin{array}{c}\text { Sample } \\
\text { coverage } \\
\text { (completeness) }\end{array}$ & $f_{1}$ & $f_{2}$ & $f_{3}$ & $f_{4}$ & $f_{5}$ & $f_{6}$ \\
\hline Lower & ast 265 & 216 & $30.3 \%$ & 185 & 21 & 6 & 1 & 2 & 1 \\
\hline Upper & ast 499 & 398 & $34.1 \%$ & 329 & 49 & 12 & 4 & 4 & 0 \\
\hline North & 292 & 218 & $42.2 \%$ & 169 & 32 & 11 & 4 & 2 & 0 \\
\hline
\end{tabular}

Note: $f_{k}$ denotes the number of classes represented by exactly $k$ individuals in the sample.

B. Observed Diversities and the Estimated Asymptotes of Diversities in the Lower Southeast.

\begin{tabular}{|c|c|c|c|c|c|}
\hline & $\begin{array}{c}\text { Observed } \\
\text { richness }\end{array}$ & $\begin{array}{l}\text { Estimated } \\
\text { asymptote }\end{array}$ & $\begin{array}{c}\text { Estimated } \\
\text { s.e. }\end{array}$ & $\begin{array}{c}95 \% \text { lower } \\
\text { confidence } \\
\text { interval }\end{array}$ & $\begin{array}{c}95 \% \text { upper } \\
\text { confidence } \\
\text { interval }\end{array}$ \\
\hline Class richness & 216 & 1027.8 & 215.5 & 702.8 & 1569.9 \\
\hline Shannon diversity (common class richness) & 195.0 & 826.3 & 98.5 & $633.3^{*}$ & $1019.3 *$ \\
\hline Simpson diversity (dominant class richness) & 165.2 & 437.3 & 77.7 & $285.0^{*}$ & $589.5^{*}$ \\
\hline
\end{tabular}

*Interval does not overlap with the interval for the Upper Southeast.

C. Observed Diversities and the Estimated Asymptotes of Diversities in the Upper Southeast.

\begin{tabular}{lccccc}
\hline & Observed & Estimated & Estimated & $\begin{array}{c}95 \% \text { lower } \\
\text { confidence } \\
\text { interval }\end{array}$ & $\begin{array}{c}95 \% \text { upper } \\
\text { confidence } \\
\text { interval }\end{array}$ \\
\hline Class richness & 398 & 1500.3 & 201.7 & $1170.4^{*}$ & $1971.1^{*}$ \\
Shannon diversity (common class richness) & 360.8 & 1274.6 & 99.6 & $1079.4^{* \#}$ & $1469.8^{* \#}$ \\
Simpson diversity (dominant class richness) & 312.4 & 833.9 & 83.1 & $670.9 * \#$ & $996.9 * \#$ \\
\hline
\end{tabular}

* Interval does not overlap with the interval for the Northwest.

\# Interval does not overlap with the interval for the Lower Southeast.

D. Observed Diversities and the Estimated Asymptotes of Diversities in the Northeast.

\begin{tabular}{|c|c|c|c|c|c|}
\hline & $\begin{array}{c}\text { Observed } \\
\text { richness }\end{array}$ & $\begin{array}{c}\text { Estimated } \\
\text { asymptote }\end{array}$ & $\begin{array}{c}\text { Estimated } \\
\text { s.e. }\end{array}$ & $\begin{array}{c}95 \% \text { lower } \\
\text { confidence } \\
\text { interval }\end{array}$ & $\begin{array}{c}95 \% \text { upper } \\
\text { confidence } \\
\text { interval }\end{array}$ \\
\hline Class richness & 218 & 662.7 & 106.3 & $498.2 *$ & $924.0^{*}$ \\
\hline Shannon diversity (common class richness) & 194.3 & 553.4 & 62.4 & $431.0 *$ & $675.7^{*}$ \\
\hline Simpson diversity (dominant class richness) & 167.2 & 389.8 & 42.3 & $306.8 *$ & $472.7 *$ \\
\hline
\end{tabular}

* Interval does not overlap with the interval for the Upper Southeast.

\section{Southeast vs. Northeast}

All plots exhibit a consistent pattern, with the diversity curve for the Southeast lying above the curve of the Northeast for all three measures (Table 3, Figure 3). Although nearly all the 95 percent CIs for the two areas in the sample-sizebased rarefaction/extrapolation sampling curves overlap and are thus inconclusive, all the coverage-based intervals are disjoint and provide sufficient evidence that the Southeast is significantly more diverse than the Northeast for the range of sample sizes and of sample-coverage values con- sidered in Figure 3. For class richness, because of undetected rare classes, we conclude that the Southeast is significantly more diverse than the Northeast up to a 60 percent fraction of the assemblage size (the upper right panel in Figure 3). For sample coverage greater than 60 percent, data are insufficient to warrant a conclusion. For common and dominant classes, the diversity of the Southeast is significantly higher than that of the Northeast, not only for the coverage plotted in Figure 3 but also for any range of coverage up to complete coverage. As stated earlier, extrapolation for Shannon and Simpson diversity, but rarely 


\section{Class richness $(q=0)$}
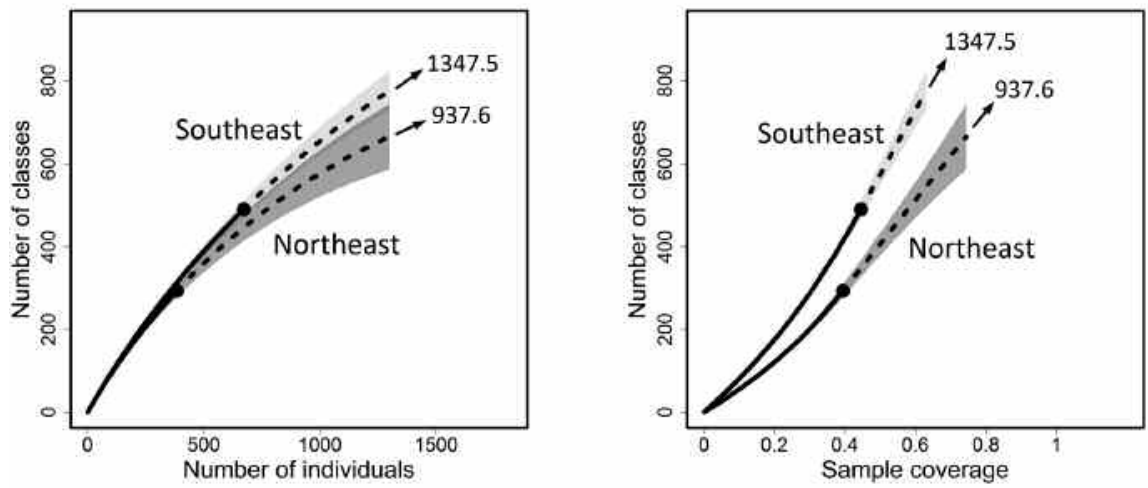

\section{Common class richness $(q=1)$}
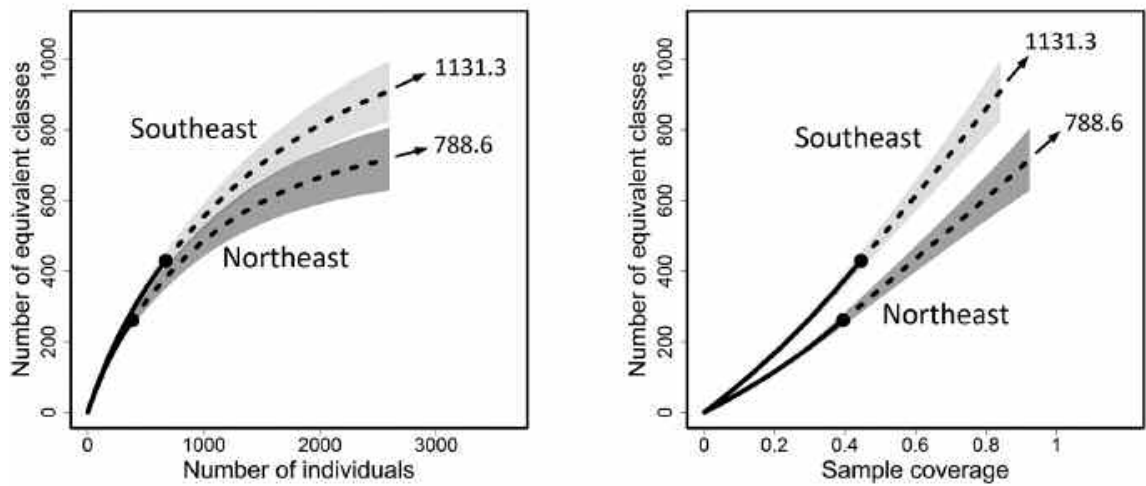

\section{Dominant class richness $(q=2)$}
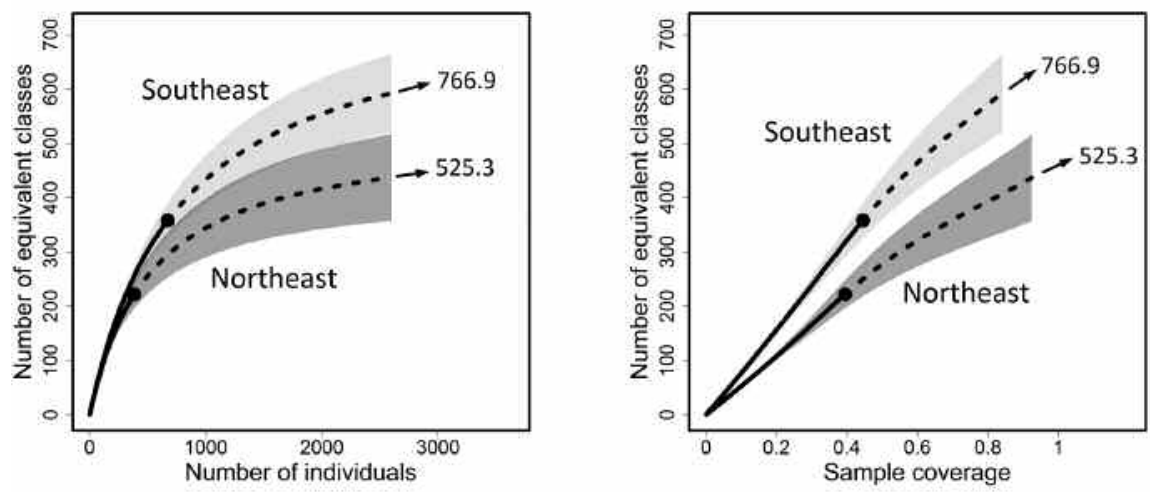

Figure 3. (Unmerged traits) Comparison of sample-size-based (left panels) and sample-coverage-based (right panels) rarefaction and extrapolation for class richness (upper panels), Shannon diversity (middle panels), and Simpson diversity (lower panels) for the Southeast and the Northeast data. Observed samples are denoted by solid dots; rarefied segments are denoted by solid lines and extrapolated segments by broken lines. The extrapolation extends up to a maximum sample size of 1,300 for class richness and to a maximum sample size of 2,600 for Shannon diversity and Simpson diversity. The sample-coverage-based extrapolation extends to the coverage value of the corresponding maximum sample size, for each sample. The 95 percent confidence intervals (shaded areas) were obtained by a bootstrap method based on 200 replications. The estimated asymptote of diversity for each curve is shown next to the arrow at the right-hand end of each curve. 


\section{Class richness $(q=0)$}
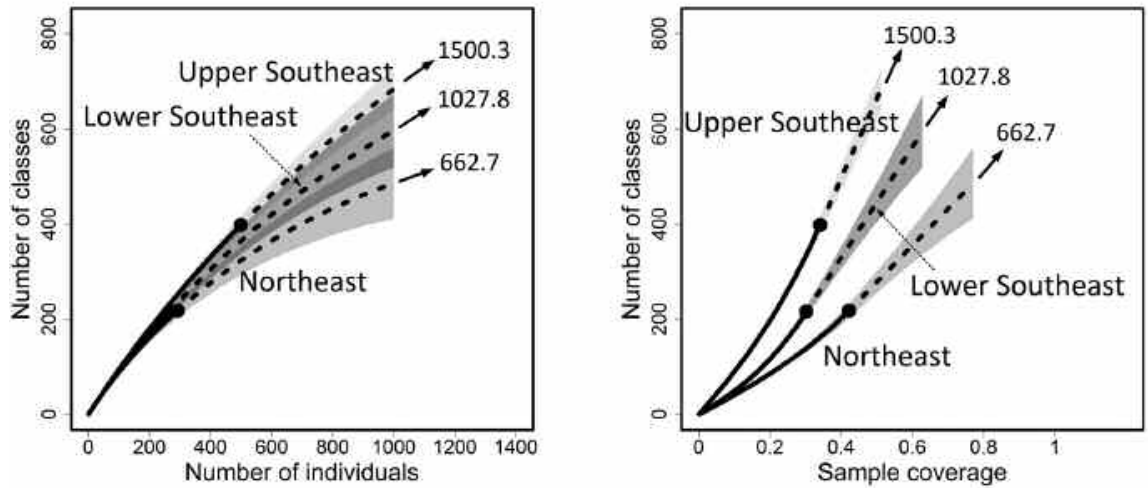

Common class richness $(q=1)$
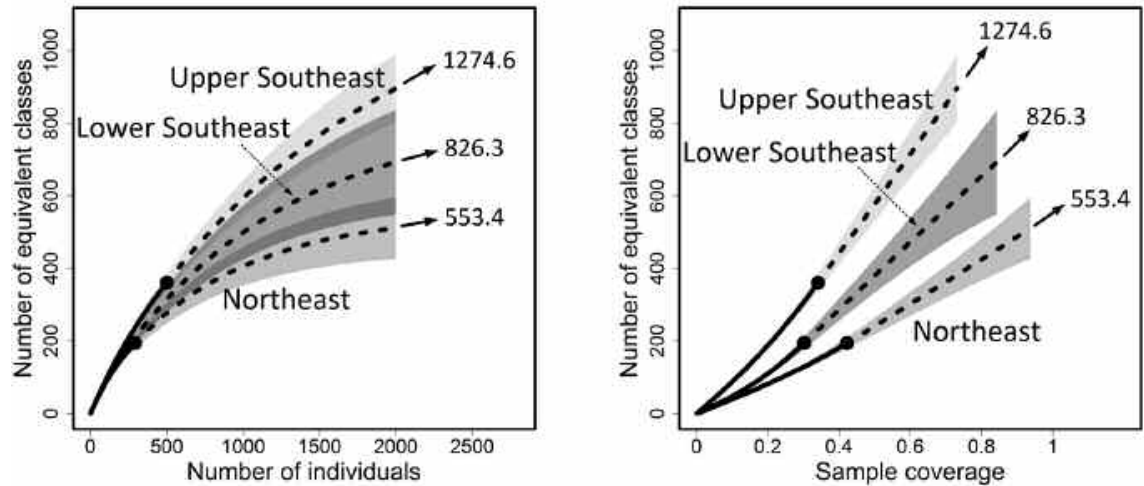

Dominant class richness $(q=2)$
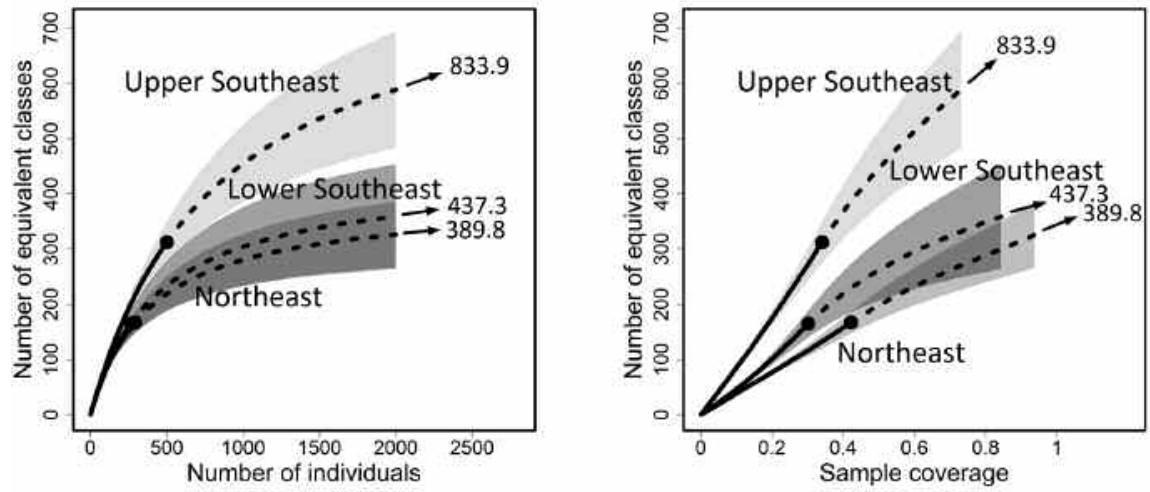

Figure 4. (Unmerged traits) Comparison of sample-size-based (left panels) and sample-coverage-based (right panels) rarefaction and extrapolation for class richness (upper panels), Shannon diversity (middle panels), and Simpson diversity (lower panels) for the Lower Southeast, the Upper Southeast, and the Northeast data. Observed samples are denoted by solid dots; rarefied segments are denoted by solid lines; and extrapolated segments by broken lines. The extrapolation extends up to a maximum sample size of 1,000 for class richness, and to a maximum sample size of 2,000 for Shannon diversity and Simpson diversity. The sample-coverage-based extrapolation extends to the coverage value of the corresponding maximum sample size, for each sample. The 95 percent confidence intervals (shaded areas) were obtained by a bootstrap method based on 200 replications. The estimated asymptote of diversity for each curve is shown next to the arrow at the right-hand end of each curve. 
class richness, can often be reliably extended to infinity or complete coverage to reach the estimated asymptote. This pattern is supported by examining the CIs for the estimated asymptotes of diversities (Table 3; shown in Figure 3 next to an arrow at the right-hand end of each plot). Notice in Table 3 that the CI of the estimated asymptote of common class diversity (Shannon diversity) in the Southeast does not overlap with the CI for the Northeast, implying significant difference. A similar conclusion is supported for dominant class diversity (Simpson diversity). This result suggests that evenness among the classes may be greater in the Southeast. In summary, our data provide sufficient evidence that the Southeast is significantly more diverse than the Northeast for common and dominant classes of projectile points. However, the data do not provide sufficient information to compare the projectile-point richness for the two entire assemblages, but the data do support the same conclusion up to a 60 percent fraction of the assemblages.

\section{Upper Southeast vs. Lower Southeast vs. Northeast}

All plots exhibit the consistent pattern that the Upper Southeast $>$ Lower Southeast $>$ Northeast for the range of sample sizes and sample coverage considered in Figure 4. From the coverage-based curves (right panels in Figure 4) and the CIs for the estimated asymptotes, we can extract additional useful information to infer whether the Upper Southeast is significantly richer than the Lower Southeast or the Northeast, as conjectured by Broster et al. (2013). Our analyses reveal that for common classes (middle right panel) and dominant classes (lower right panel), the Upper Southeast is significantly more diverse than the Northeast. This conclusion can be extended to the asymptotes, as shown by the nonoverlapping CIs in Table 4. For class richness, although the two CIs of the asymptotes are disjoint, data support the same conclusion up to a 50 percent fraction of the assemblage size (upper right panel). Similar comparisons also hold for the Upper Southeast and the Lower Southeast. In summary, our analyses confirm that the Upper Southeast is significantly richer than the Lower Southeast or the Northeast for common and dominant projectile points. However, for projectile-point richness, such a conclusion is supported by data up to a 50 percent fraction of the assemblages.

\section{Discussion}

For the first time, Mason's proposal that the southeastern United States contains greater Paleoindian projectile-point diversity than other regions was tested by statistically comparing paradigmatic class richness between the Northeast and the Southeast. Our results were consistent with Mason's hypothesis that the Southeast, as defined by Anderson (1990), does indeed exhibit greater projectile-point diversity than its neighboring region. Some archaeologists might question whether our use of paradigmatic classes, which are different point categories than Mason (1962) and others have used, is inappropriate for testing a hypothesis that was proposed with the latter in mind. Put simply, our approach is more rigorous than Mason's, since we classified points in a quantitative, replicable, and explicit manner, ensuring that assessments of point diversity across eastern North America are not biased because archaeologists or collectors in the Northeast are "lumpers" whereas in the Southeast they are "splitters," or because archaeologists in the two regions define point types in fundamentally different ways. Further, rather than use intuitive, qualitative modeling as Mason (1962) did to assess diversity, we used quantitative measures because although "intuitive qualitative modeling can be a very useful thing. . . it can also lead us to incorrect conclusions" (Surovell 2009:xiv; see also Eren et al. 2013, 2014; Lycett and Chauhan 2010). However, because we acknowledge that some archaeologists may still be skeptical of a point design space that encompasses 217,728 classes, we note that in the supplemental materials (Supplemental Tables 1 and 2, Supplemental Figures 1 and 2) we present additional statistical analyses of paradigmatic classes formed by more broadly defined character states. This procedure resulted in a design space of only 2,916 classes - a much smaller number than the 217,728 classes used for the above analyses - and provided even stronger evidence and more consistent and clearer patterns in support of Mason's (1962) proposal.

Before making any conclusions about Clovis "origins" or "homelands," however, we emphasize 
that, although our results support Mason's proposal, more analyses are necessary. Future tests should focus on acquiring larger samples, better geographic coverage, and perhaps most important, projectile-point-class data from western North America. Until a statistical projectile-point diversity comparison is conducted between the southeastern United States and western regions (e.g., the Southwest), it is invalid to use point diversity as evidence for a Clovis origin in the Southeast, especially in light of current chronometric evidence that suggests the opposite (Ferring 2001; Hamilton and Buchanan 2007; Sanchez et al. 2014; Waters et al. 2011).

In fact, greater levels of Paleoindian point diversity may have little to do with "origins" or "homelands," at least on a continental scale. As mentioned earlier, river valleys in the Upper Southeast have often been interpreted to be colonization corridors for early Paleoindians moving from west to east (Anderson 1990, 1996). If a founding population from western North America first entered the Upper Southeast by way of the Missouri, Arkansas, Mississippi, Ohio, Cumberland, and/or Tennessee River valleys, then as these populations subsequently spread to the Lower Southeast and to the Northeast, we can reasonably predict there to have been less chance for the accumulation of changes in these latter two regions relative to the Upper Southeast. It is thus intriguing that this prediction is corroborated in our second analysis of point diversity, which directly compared the Upper Southeast to the Lower Southeast and the Northeast and found consistently greater point diversity in the Upper Southeast relative to these other regions (see also the Supplemental Materials).

If indeed the Upper Southeast represents the geographic "landfall" for a founding population in eastern North America, why do not the Lower Southeast and the Northeast possess similar levels of projectile-point diversity, if they were both colonized subsequently? In other words, why does the Lower Southeast consistently exhibit greater diversity than the Northeast? We propose that the role of environments in supporting forager populations may have contributed to this pattern. Because the Lower Southeast possessed warmer and more productive environments relative to the Northeast, perhaps it would have been able to support denser and larger Paleoindian populations relative to the Northeast (Steele et al. 1998). These larger populations would have perhaps allowed the Lower Southeast to accumulate changes at a faster rate than that experienced by the relatively smaller populations of the Northeast. Another cultural casualty of the Northeast's smaller populations (see Henrich 2004, Lycett and Norton 2010, Neiman 1995, and Shennan 2000 for similar arguments) may have been prismatic blade technology (Eren 2013; see also Beck and Jones 2010; Eren and Redmond 2011; Kilby 2015), which, as projectile-point diversity declines geographically, seems to disappear. Readers who may be skeptical of our state-by-state definition of the Upper Southeast should note that we carried out an additional set of analyses that instead defined the Upper Southeast more traditionally: northern Alabama (above $34^{\circ} \mathrm{N}$ latitude), Arkansas, Kentucky, northern Mississippi (above $34^{\circ} \mathrm{N}$ latitude), Missouri, and Tennessee (see supplemental materials). We compared this Tennessee River valley against a newly defined Southeast as well as the Northeast. The results of these analyses showed even stronger support for a greater diversity in the Upper Southeast (see online supplemental materials).

Investigating and evaluating the scenarios discussed above regarding "homelands," "fissioning" (e.g., Anderson 1990; Beck and Jones 2010), or other possible hypotheses (Lycett and von Cramon-Tabuadel 2008) and artifact life-history processes, for example differential resharpening (Buchanan et al. 2015), will require several additional analyses as well as contributions from fieldwork, dating studies, and quantitative methods. However, given that these scenarios depend on accurate and replicable assessments of artifact diversity, it is important that quantitative assessments of artifact diversity using the tools of ecological biodiversity be carried out. The results presented here are a small step toward that goal.

Acknowledgments. MIE was financially supported by a University of Missouri postdoctoral fellowship. RKC was supported by the Coordenação de Aperfeiçoamento de Pessoal de Nível Superior (CAPES), Brazil. AC is supported by Taiwan Ministry of Science and Technology under Contract 1032628-M007-007. CHC is supported by a postdoctoral fellowship, National Tsing Hua University, Taiwan. This manuscript benefitted greatly from discussions with Stephen Lycett, Noreen von Cramon-Taubadel, and David Meltzer. We also thank Cristo Hernández for preparing the Spanish abstract, which was checked by Roxana Cattaneo. 
Supplemental Materials. Supplemental materials are linked to the online version of the paper, which is accessible via the SAA member login at www.saa.org/members-login.

Supplemental Material 1. Excel file with references to all point specimens.

Supplemental Material 2. Statistical analyses for merged traits.

Supplemental Material 3. Statistical analysis of unmerged and merged traits comparing the Tennessee River valley versus the Southeast versus the Northeast.

Supplemental Table 1. (Merged traits) Data summary for the Southeast and the Northeast, with statistical inference for estimated asymptotes of diversities.

Supplemental Table 2. (Merged traits) Data summary for the Lower Southeast, Upper Southeast, and Northeast, with statistical inference for estimated asymptotes of diversities.

Supplemental Table 3. (Unmerged traits) Data summary for the Tennessee River valley, the Southeast, and the Northeast together with statistical inference for estimated asymptotes of diversities.

Supplemental Table 4. (Merged traits) Data summary for the Tennessee River valley, the Southeast, and the Northeast together with statistical inference for estimated asymptotes of diversities.

Supplemental Figure 1. (Merged traits) Comparison of sample-size-based and sample-coverage-based rarefaction and extrapolation for class richness, Shannon diversity, and Simpson diversity for the Southeast and the Northeast data.

Supplemental Figure 2. (Merged traits) Comparison of sample-size-based and sample-coverage-based rarefaction and extrapolation for class richness, Shannon diversity, and Simpson diversity for the Upper Southeast, Lower Southeast, and Northeast data.

Supplemental Figure 3. (Unmerged traits) Comparison of sample-size-based and sample-coverage-based rarefaction and extrapolation for class richness, Shannon diversity, and Simpson diversity for the Tennessee River valley, the Southeast, and the Northeast.

Supplemental Figure 4. (Merged traits) Comparison of sample-size-based and sample-coverage-based rarefaction and extrapolation for class richness, Shannon diversity, and Simpson diversity for the Tennessee River valley, the Southeast, and the Northeast.

\section{References Cited}

Anderson, David G.

1990 The Paleoindian Colonization of Eastern North America: A View from the Southeastern United States. In Early Paleoindian Economies of Eastern North America, edited by Kenneth B. Tankersely and Barry L. Isaac, pp. 163-216. JAI Press, Greenwich, Connecticut.

1996 Models of Paleoindian and Early Archaic Settlement in the Southeastern United States. In The Paleoindian and Early Archaic Southeast, edited by David G. Anderson and Kenneth E. Sassaman, pp. 29-57. University of Alabama Press, Tuscaloosa.

2013 Paleoindian Archaeology in Eastern North America:
Current Approaches and Future Directions. In In the Eastern Fluted Point Tradition, edited by Joseph A. M. Gingerich, pp. 371-403. University of Utah Press, Salt Lake City.

Anderson, David G., and Michael K. Faught

1998 The Distribution of Fluted Paleoindian Projectile Points: Update 1998. Archaeology of Eastern North America 26:163-187.

2000 Palaeoindian Artefact Distributions: Evidence and Implications. Antiquity 74:507-513.

Anderson, David G., and J.C.Gillam

2000 Paleoindian Colonization of the Americas: Implications from an Examination of Physiography, Demography, and Artifact Distribution. American Antiquity 65:43-66.

Anderson, David G., R. Jerald Ledbetter, and Lisa O'Steen 1990 Paleoindian Period Archaeology of Georgia. Laboratory of Archaeology Series Report No. 28. University of Georgia, Athens.

Anderson, David G., D. Shane Miller, Stephen J. Yerka, J. Christopher Gillam, Erik N. Johanson, Derek T. Anderson, Albert C. Goodyear, and Ashley M. Smallwood

2010 PIDBA (Paleoindian Database of the Americas) 2010 Current Status and Findings. Archaeology of Eastern North America 38:63-89.

Barton, C. Michael, Geoffrey A. Clark, David R. Yesner, and Georges A. Pearson (editors)

2004 The Settlement of the American Continents: A Multidisciplinary Approach to Human Biogeography. University of Arizona Press, Tucson

Beck, Charlotte, and George T. Jones

1989 Bias and Archaeological Classification. American Antiquity 54:244-263.

2010 Clovis Western Stemmed: Population Migration and the Meeting of Two Technologies in the Intermountain West. American Antiquity 75:81-116.

Bradley, Bruce A., Michael_B_Collins, and Andrew Hemmings

2010 Clovis Technology. International Monographs in Prehistory, Ann Arbor.

Brennan, Louis A

1982 A Compilation of Fluted Points of Eastern North America by Count and Distribution: An AENA Project. Archaeology of Eastern North America 10:27-46.

Broster, John B., Mark Norton, D. Shane Miller, Jesse W. Tune, and Jon D. Baker

2013 Tennessee Paleoindian Record: The Cumberland and Lower Tennessee River Watersheds. In In the Eastern Fluted Point Tradition, edited by Joseph A. M. Gingerich, pp. 299-314. University of Utah Press, Salt Lake City.

Bryan, Allen L.

1991 The Fluted-point Tradition in the Americas - One of Several Adaptations to Late Pleistocene American Environments. In Clovis: Origins and Adaptations, edited by Robson Bonnichsen and Karen L. Turnmire, pp. 15-33. Center for the Study of the First Americans, Corvallis, Oregon.

Buchanan, Briggs

2003 The Effects of Sample Bias on Paleoindian Fluted Point Recovery in the United States. North American Archaeologist 24:311-338.

Buchanan, Briggs, Metin I. Eren, Matthew T. Boulanger, and Michael J. O'Brien

2015 Size, Shape, Scars, and Spatial Patterning: A Quantitative Assessment of Late Pleistocene (Clovis) Point Resharpening. Journal of Archaeological Science: Reports 3:11-21.

Byers, Douglas S. 
1959 The Eastern Archaic: Some Problems and Hypotheses. American Antiquity 24:233-256.

Carr, Philip, and Andrew Bradbury

2000 Contemporary Lithic Analysis and Southeastern Archaeology. Southeastern Archaeology 19:120-134.

Chao, Anne

1984 Nonparametric Estimation of the Number of Classes in a Population. Scandinavian Journal of Statistics 11:265270.

2005 Species Estimation and Applications. In Encyclopedia of Statistical Sciences , 2nd ed., vol. 12, edited by N. Balakrishnan, Campbell B. Read, and Brani Vidakovic, pp. 7907-7916. Wiley, New York.

Chao, Anne, Nicholas J. Gotelli, T. C. Hsieh, Elizabeth L. Sander, K. H. Ma, Robert K. Colwell, and Aaron M. Ellison

2014 Rarefaction and Extrapolation with Hill Numbers: A Framework for Sampling and Estimation in Species Diversity Studies. Ecological Monographs 84:45-67.

Chao, Anne, and Lou Jost

2012 Coverage-Based Rarefaction and Extrapolation: Standardizing Samples by Completeness Rather Than Size. Ecology 93:2533-2547.

Chao, Anne, Y. T. Wang, and Lou Jost

2013 Entropy and the Species Accumulation Curve: A Novel Entropy Estimator via Discovery Rates of New Species. Methods in Ecology and Evolution 4:10911100.

Colwell, Robert K., Anne Chao, Nicholas J. Gotelli, Shang-Yi Lin, Chang Xuan Mao, Robin L. Chazdon, and John T. Longino

2012 Models and Estimators Linking Individual-based and Sample-based Rarefaction, Extrapolation and Comparison of Assemblages. Journal of Plant Ecology 5:321.

Colwell, Robert K., and Jonathan A. Coddington

1994 Estimating Terrestrial Biodiversity through Extrapolation. Philosophical Transactions of the Royal Society of London B 345:101-118.

Dunnell, RobertC

1971 Systematics in Prehistory. Free Press, New York.

Ellis, Chistopher

2004 Understanding "Clovis" Fluted Point Variability in the Northeast: A Perspective from the Debert Site, Nova Scotia. Canadian Journal of Archaeology 28:205-253.

Eren, Metin I.

2012 Were Unifacial Tools Regularly Hafted by Clovis Foragers in the North American Lower Great Lakes Region? An Empirical Test of Edge Class Richness and Attribute Frequency among Distal, Proximal, and Lateral Tool-Section. Journal of Ohio Archaeology 2:1-15.

2013 The Technology of Stone Age Colonization: An Empirical, Regional-Scale Examination of Clovis Unifacial Stone Tool Reduction, Allometry, and Edge Angle from the North American Lower Great Lakes Region. Journal of Archaeological Science 40:2101-2112.

Eren, Metin I., Briggs Buchanan, and Michael J. O'Brien

2015 Social Learning and Technological Evolution during Clovis Colonization of the New World. Journal of Human Evolution 80:159-170.

Eren, Metin I., Anne Chao, Wen-Han Hwang, and Robert K. Colwell

2012 Estimating the Richness of a Population When the Maximum Number of Classes Is Fixed: A Nonparametric Solution to an Archaeological Problem. PLOS ONE 7(5):e34179.

Eren, Metin I., and Brian Redmond

2011 Clovis Blades at Paleo Crossing (33ME274), Medina
County, Ohio. Midcontinental Journal of Archaeology 36:173-194.

Eren, Metin I., Robert J. Patten, Michael J. O'Brien, and David J. Meltzer

2013 Refuting the Technological Cornerstone of the IceAge Atlantic Crossing Hypothesis. Journal of Archaeological Science 40:2934-2941

2014 More on the Rumor of "Intentional Overshot Flaking" and the Purported Ice-Age Atlantic Crossing. Lithic Technology 39:55-63.

Faught, Michael K.

2006 Paleoindian Archaeology in Florida and Panama: Two Circumgulf Regions Exhibiting Waisted Lanceolate Projectile Points. In Ice Age Occupations of the Americas A Hemispheric Perspective, edited by Juliet E. Morrow and Cristóbal Gnecco, pp. 164-183. University Press of Florida, Gainesville.

Ferring, C. Reid

2001 The Archaeology and Paleoecology of the Aubrey Clovis Site (41DN479), Denton County, Texas. Center for Environmental Archaeology, Department of Geography, University of North Texas, Denton.

Gini, Corrado

1912 Variabilità e Mutabilità. Reprinted in Memorie di Metodologia Statistica, edited by E. Pizetti and T. Salvemini. Libreria Eredi Virgilio Veschi, Rome.

Good, I. J.

1953 The Population Frequencies of Species and the Estimation of Population Parameters. Biometrika 40:237264.

2000 -Turing's Anticipation of Empirical Bayes in Connection with the Cryptanalysis of the Naval Enigma. Journal of Statistical Computation and Simulation 66:101-111.

Gotelli, Nicholas J., and Anne Chao

2013 Measuring and Estimating Species Richness, Species Diversity, and Biotic Similarity from Sampling Data. In Encyclopedia of Biodiversity, 2nd ed., vol. 5, edited by Simon A. Levin, pp. 195-211. Academic Press, Waltham, Massachusetts.

Gotelli, Nicholas J., and Robert K. Colwell

2011 Estimating Species Richness. In Frontiers in Measuring Biodiversity, edited by Anne E. Magurran and Brian J. McGill, pp. 39-54. Oxford University Press, New York.

Greenman, Emerson F.

1963 The Upper Palaeolithic and the New World. Current Anthropology 4:41-91.

Haavie, J., G.-P. Saetre, and T. Moum

2000 Discrepancies in Population Differentiation at Microsatellites, Mitochondrial DNA and Plumage Colour in the Pied Flycatcher - Inferring Evolutionary Processes. Molecular Ecology 9:1137-1148.

Halligan,Jess

2013 Reconstructing the Pleistocene Environment of the Greater Southeast. In In the Eastern Fluted Point Tradition, edited by Joseph A. M. Gingerich, pp. 58-72. University of Utah Press, Salt Lake City.

Hamilton, Marcus J., and Briggs Buchanan

2007 Spatial Gradients in Clovis-Age Radiocarbon Dates across North America Suggest Rapid Colonization from the North. Proceedings of the National Academy of Sciences 104:15625-15630.

Haynes, C. Vance

1983 Fluted Points in the East and West. Archaeology of Eastern North America 11:24-26.

Haynes, Gary

2002 The Early Settlement of North America: The Clovis Era. Cambridge University Press, Cambridge. 
Henrich, Joseph

2004 Demography and Cultural Evolution: Why Adaptive Cultural Processes Produced Maladaptive Losses in Tasmania. American Antiquity 69:197-221.

Hill, Mark O.

1973 Diversity and Evenness: A Unifying Notation and Its Consequences. Ecology 54:427-432.

Holliday, Vance T., and D. Shane Miller

2014 The Clovis Landscape. In Paleoamerican Odyssey, edited by Kelly E. Graf, Caroline V. Ketron, and Michael R. Waters, pp. 221-245. Texas A\&M University Press, College Station.

Jost, Lou

2007 Partitioning Diversity into Independent Alpha and Beta Components. Ecology 88:2427-2439.

Kilby, David

2015 A Regional Perspective on Clovis Blades and Caching Behavior. In Clovis: On the Edge of a New Understanding, edited by Ashley M. Smallwood and Thomas A. Jennings, pp. 145-159. Texas A\&M University Press, College Station.

Leberg, P. L.

2002 Estimating Allelic Richness: Effects of Sample Size and Bottlenecks. Molecular Ecology 11:2445-2449.

Lepper, Bradley T.

1983 Fluted Point Distributional Patterns in the Eastern United States: A Contemporary Phenomenon. Midcontinental Journal of Archaeology 8:269-285.

1985 The Effects of Cultivation and Collecting on Ohio Fluted Point Finds: A Reply to Seeman and Prufer. Midcontinental Journal of Archaeology 10:241-250.

Loebel, Thomas J.

2012 Pattern or Bias? A Critical Evaluation of Midwestern Fluted Point Distributions Using Raster Based GIS. Journal of Archaeological Science 39:1205-1217.

Lycett, Stephen J.

2008 Acheulean Variation and Selection: Does Handaxe Symmetry Fit Neutral Expectations? Journal of Archaeological Science 35:2640-2648.

Lycett, Stephen J., and Parth R. Chauhan

2010 Analytical Approaches to Palaeolithic Technologies: An Introduction. In New Perspectives on Old Stones, edited by Stephen J. Lycett and Parth R. Chauhan, pp. 122, Springer, New York.

Lycett, Stephen J., and Noreen von Cramon-Taubadel

2008 Acheulean Variability and Hominin Dispersals: A Model-Bound Approach. Journal of Archaeological Science 35:553-562.

Lycett, Stephen J., and Christopher Norton

2010 A Demographic Model for Palaeolithic Technological Evolution: The Case of East Asia and the Movius Line. Quaternary International 211:55-65.

Lyman, R. Lee

2008 Quantitative Paleozoology. Cambridge University Press, Cambridge.

Lyman, R. Lee, and Todd VanPool

2009 Metric Data in Archaeology: A Study of Intra-Analyst and Inter-Analyst Variation. American Antiquity 74:485504 .

MacArthur, Robert H.

1965 Patterns of Species Diversity. Biological Review 40:510-533.

Magurran, Anne E.

2004 Measuring Biological Diversity. Blackwell, Malden, Massachusetts.

Mason, Ronald J.

1962 The Paleo-Indian Tradition in Eastern North America. Current Anthropology 3:227-278.
Meltzer, David J.

1981 A Study of Style and Function in a Class of Tools. Journal of Field Archaeology 8:313-326.

1984 Late Pleistocene Human Adaptations in Eastern North America. Unpublished Ph.D. dissertation, Department of Anthropology, University of Washington, Seattle.

1986 The Clovis Paleoindian Occupation of Texas: Results of the Texas Clovis Fluted Point Survey. Bulletin of the Texas Archeological Society 57:27-68.

2004 Modeling the Initial Colonization of the Americas: Issues of Scale, Demography, and Landscape Learning. In The Settlement of the American Continents: A Multidisciplinary Approach to Human Biogeography, edited by C. Michael Barton, Geoffrey A. Clark, David R. Yesner, and Georges A. Pearson, pp. 123-137. University of Arizona Press, Tucson.

2009 First Peoples in a New World: Colonizing Ice Age America. University of California Press, Berkeley.

Miller, D. Shane, and Joseph A. M. Gingerich

2013a Paleoindian Chronology and the Eastern Fluted Point Tradition. In In the Eastern Fluted Point Tradition, edited by Joseph A. M. Gingerich, pp. 9-37. University of Utah Press, Salt Lake City.

2013b Regional Variation in the Terminal Pleistocene and Early Holocene Radiocarbon Record of Eastern North America. Quaternary Research 79:175-188.

Miller, D. Shane, Vance T. Holliday, and Jordan Bright

2014 Clovis across the Continent. In Paleoamerican Odyssey, edited by Kelly E. Graf, Caroline V. Ketron, and Michael R. Waters, pp. 207-220. Texas A\&M University Press, College Station.

Neiman, Fraser D.

1995 Stylistic Variation in Evolutionary Perspective: Inferences from Decorative Diversity and Interassemblage Distance in Illinois Woodland Ceramic Assemblages. American Antiquity 60:7-36.

Nolan, KevinC., and Robert A.Coo

2011 A Critique of Prehistoric Systematics in the Middle Ohio River Valley. North American Archaeologist 32:293325 .

O’Brien, Michael J., Matthew T. Boulanger, Briggs Buchanan, Mark Collard, and R. Lee Lyman

2014 Innovation and Cultural Transmission in the American Paleolithic: Phylogenetic Analysis of Eastern Paleoindian Projectile-Point Classes. Journal of Anthropological Archaeology 34:100-119.

O'Brien, Michael J., Briggs Buchanan, Matthew T. Boulanger, Alex Mesoudi, Mark Collard, Metin I. Eren, R. Alex Bentley, and R. Lee Lyman

2015 Transmission of Cultural Variants in the North American Paleolithic. In Learning Strategies and Cultural Evolution during the Paleolithic, edited by K. Aoki and A. Mesoudi, pp. 121-142. Springer: New York.

O’Brien, Michael J., John Darwent, and R. Lee Lyman

2001 Cladistics Is Useful for Reconstructing Archaeological Phylogenies: Palaeoindian Points from the Southeastern United States. Journal of Archaeological Science 28:11151136.

O'Brien, Michael J., and R. Lee Lyman

2000 Applying Evolutionary Archaeology: A Systematic Approach. Kluwer Academic/Plenum, New York.

2002 The Epistemological Nature of Archaeological Units Anthropological Theory 2:37-56.

2009 Darwinism and Historical Archaeology. In International Handbook of Historical Archaeology, edited by Teresita Majewski and David Gaimster, pp. 227-252. Springer: New York. 
O’Brien, Michael J., R. Lee Lyman, Youssef Saab, Elias Saab, John Darwent, and Daniel S. Glover

2002 Two Issues in Archaeological Phylogenetics: Taxon Construction and Outgroup Selection. Journal of Theoretical Biology 215:133-150.

Prasciunas, Mary M.

2011 Mapping Clovis: Projectile Points, Behavior, and Bias. American Antiquity 76:107-126.

Prugnolle, Eranck, Andrea Mancia and François Balloux

2005 Geography Predicts Neutral Genetic Diversity of Human Populations. Current Biology 15:159-160.

Roberts, Frank H. H.

1939 The Folsom Problem in American Archaeology. In Smithsonian Institution Annual Report 1938, pp. 531543. Smithsonian Institution, Washington, D.C.

Sanchez, Guadalupe, Vance T. Holliday, Edmund P. Gaines, Joaquín Arroyo-Cabrales, Natalia Martínez-Tagüeña, Andrew Kowler, Todd Lange, Gregory W. L. Hodgins, Susan M. Mentzer, and Ismael Sanchez-Morales

2014 Human (Clovis)-Gomphothere (Cuvieronius sp.) Association ?13,390 Calibrated yBP in Sonora, Mexico. Proceedings of the National Academy of Sciences 111:10972-10977.

Seeman, Mark F., and Olaf H. Prufer

1982 An Updated Distribution of Ohio Fluted Points. Midcontinental Journal of Archaeology 7:155-169.

1984 The Effects of Cultivation and Collecting on Ohio Fluted Point Finds: A Cautionary Note. Midcontinental Journal of Archaeology 9:227-233.

Shannon, Claude E.

1948 The Mathematical Theory of Communication. Bell System Technical Journal 27:379-423.

Shennan, Stephen J.

2000 Population, Culture History, and the Dynamics of Culture Change. Current Anthropology 41:811-835.

Sholts, Sabrina B., Dennis_J.Stanford,_Lowise M.Flores, and Sebastian K. T. S. Wärmländer

2012 Flake Scar Patterns of Clovis Points Analyzed with a New Digital Morphometrics Approach: Evidence for Direct Transmission of Technological Knowledge across Early North America. Journal of Archaeological Science 39:3018-3026.

Shott, Michael J

2002 Sample Bias in the Distribution and Abundance of Midwestern Fluted Bifaces. Midcontinental Journal of Archaeology 27:89-123.

Simpson, George G.

1943 Mammals and the Nature of Continents. American Journal of Science 241:1-31.

Smallwood, Ashley M.

2012 Clovis Technology and Settlement in the American Southeast: Using Biface Analysis to Evaluate Dispersal Models. American Antiquity 77:689-713.

Smallwood, Ashley M., and Thomas A. Jennings (editors)

2015 Clovis: On the Edge of a New Understanding. Texas A\&M University Press. College Station.

Smith, Heather L., Ashley M. Smallwood, and Thomas J. DeWitt

2015 Defining the Normative Range of Clovis Fluted Point Shape Using Geographic Models of Geometric Morphometric Variation. In Clovis: On the Edge of a New Understanding, edited by Ashley M. Smallwood and Thomas A. Jennings, pp. 161-180. Texas A\&M University Press, College Station.

Stanford, Dennis J.

1991 Clovis Origins and Adaptations: An Introductory Perspective. In Clovis: Origins and Adaptations, edited by Robson Bonnichsen and Karen L. Turnmire, pp. 1-13. Center for the Study of the First Americans, Corvallis, Oregon.

Stanford, Dennis J., and Bruce A. Bradley

2012 Across Atlantic Ice: The Origin of America's Clovis Culture. University of California Press, Berkeley.

Steele, James, Jonathan Adams, and Tim Sluckin

1998 Modelling Paleoindian dispersals. World Archaeology 30:286-305.

Surovell, Todd A

2009 Toward a Behavioral Ecology of Lithic Technology. University of Arizona Press, Tucson.

Tankersley, Kenneth B.

1989 Late Pleistocene Lithic Exploitation and Human Settlement in the Midwestern United States. Unpublished $\mathrm{Ph} . \mathrm{D}$. dissertation, Department of Anthropology, Indiana University, Bloomington

Thulman, David K.

2006 A Reconstruction of Paleoindian Social Organization in North Central Florida. Ph.D. dissertation, Department of Anthropology, Florida State University, Tallahassee.

2012 Discriminating Paleoindian Point Types from Florida Using Landmark Geometric Morphometrics. Journal of Archaeological Science 39:1599-1607.

Waters, Michael R., Steven L. Forman, Thomas A. Jennings, Lee C. Nordt, Steven G. Driese, Joshua M. Feinberg, Joshua L. Keene, Jessi Halligan, Anna Lindquist, James Pierson, Charles T. Hallmark, Michael B. Collins, and James Wiederhold

2011 The Buttermilk Creek Complex and the Origins of Clovis at the Debra L. Friedkin Site, Texas. Science 331:1599-1603.

Whittaker, John C., Douglas Caulkins, and Kathryn A. Kamp 1998 Evaluating consistency in typology and classification. Journal of Archaeological Method and Theory 5:129164

Wiant, Michael D.

1993 Exploring Paleoindian Site Distribution in Illinois. In Highways to the Past: Essays on Illinois Archaeology in Honor of Charles J. Bareis, edited by Thomas E. Emerson, Andrew C. Fortier, and Dale L. McElrath, pp. 108-118. Illinois Archaeological Survey, Champaign.

Williams, Stephen, and James B. Stoltman

1965 An Outline of Southeastern United States Prehistory with Particular Emphasis on the Paleoindian Era. In The Quaternary of the United States, edited by Herbert E. Wright and David G. Frey, pp. 669-683. Princeton University Press, Princeton, New Jersey.

\section{Notes}

1. Although Mason (1962) is the best-known early source suggesting that the southeastern United States possessed greater point diversity than other regions, other researchers were also thinking along these lines. For example, Roberts (1939:544) suggested that "on the basis of the distribution concept as an index to age - a theory substantiated in some respects by evidence that tends to indicate that there is a correlation between type and distribution, so that the larger the area covered the older the form - the eastern examples would indicate more antiquity than the western." Twenty years later, Byers (1959) suggested the same. However, it was Mason's (1962) landmark paper that first provided a synthesis of distributional data for fluted-point forms in the East and made direct comparisons to 
western point forms and their spatial distributions.

2. O'Brien et al. (2014:105) note that the Paleoindian point database consists of 1,813 specimens. This number is a typographical error; it should be 1,113 . When broken points, a small number of points outside of eastern North America, and points with incorrectly entered attributes are removed, the resulting number of specimens is 1,056. O'Brien et al. (2014) contained additional analyses that did not involve paradigmatic classification, and hence points that did not include information on all eight character traits could be included in that database that could not be included here.

3. Readers interested in the shape of specimens in some of the classes should consult O'Brien et al. (2014, especially Figures 6 and 7). As an important aside, when we took measurements of the points in the sample, we recorded the traditional type names that the original reporters used. Therefore, we could examine the distribution of type names among the classes. Not surprising, we had classes that contained specimens from as many as four to six traditional Paleoindian types. We do not deny the shorthand utility of types; we would not go to an archaeological meeting and announce that we had found a class 21213423 specimen. Rather, we would say that we had found a Clovis point. But from an analytical standpoint, the type "Clovis" has significant drawbacks, just as all types do where there is a lack of redundancy in the characters used to create the types (Ellis 2004; Faught 2006; Haynes 1983; Thulman 2012).

4. Halligan's (2013) definition of the Southeast includes all of the states listed by Anderson (1990), plus West Virginia and Maryland. However, our current database includes only two specimens from West Virginia and none from Maryland, so there would be essentially no difference in our statistical analysis were these two states included.

5. The Southeast comprises Florida (1), Louisiana (2), Mississippi (3), Alabama (4), Georgia (5), South Carolina (6), Arkansas (7), Tennessee (8), North Carolina (9), Kentucky (10), and Virginia (11). The Northeast comprises Missouri (12), Illinois (13), Indiana (14), Ohio (15), West Virginia (16), Pennsylvania (17), New Jersey (18), Ontario (19), New York (20), Connecticut (21), Massachusetts (22), Vermont (23), New Hampshire (24), Maine (25), and Nova Scotia (26).

6. We defined the Upper Southeast as the area bounded by and containing the Ohio River (1), the Tennessee River (2), the Cumberland River (3) , the Missouri River (4), the Arkansas River (5), and the Mississippi River (6).

Submitted March 1, 2015; Revised May 26, 2015; Accepted August 2, 2015. 